Journal of Business Management and
Economic Research
2018, 2(11): $38-47$ DOI: $10.29226 / T R 1001.2018 .78$
Journal Homepage: https://www.jobmer.org

\title{
The Effect of Capacity Utilization on Economic Growth in Industrial Enterprises
}

\author{
Mustafa TURHAN \\ Head of Executive Board of TROY HOLDING, İstanbul, Turkey. \\ mustur51@hotmail.com
}

\begin{abstract}
International economic and political developments, rapid changes in the field of technology in recent years, the increase in population and number of employees, and the mobilization of capital have significantly affected the development of developing countries. Influence leads to a fall in production in the real sector and also causes crises in the financial sector. Another reason for production losses is the drop in capacity utilization rates. Capacity utilization is an important factor when it is aimed to increase the speed of development and to create more added value of existing capital. For this reason, it has become important to examine the hypothesis that it is possible to increase the national income more fully by fully using the available capacity in the industry and to present analytical solutions. The idea that fixed asset investments are used at full capacity is invalid. It is frequently encountered in both developed and developing countries that the investments made in manufacturing industry are not operated at full capacity. The idle capacity created by domestic economic crises, decisions and anticipations and structural causes is a decline in the rate of development for developing countries. Because the idle capacity is resource waste.
\end{abstract}

Keywords: Capacity Utilization, Production, Manufacturing

\section{Capacity Definitions and Factors}

When it comes to producing goods and services, the quality and quantity of the production tools becomes important. Production decisions are made according to emerging needs and targets are determined based on this. Here, too, the assumptions about targets and the assumptions of goods or services that produce the effects on the means of production are also directed. For this reason, it is important that the production factors are used correctly and efficiently. 
Describes the capacity of production at a certain time interval. That is, they express how they will use the production factors in their own hands. The ability of factors in a sense. Directing existing assets and generating value from them is a factor.

In other words, it is possible to define the value of realization as target, level, characteristic, quantity-quality, phase, level, efficient use of resources and efficiency are among the capacity definitions to be sustained by their measurementand regulation (Otoo-Agaptova-Behrens, 2009, 2).

The measurement of production in the enterprises and the evaluation of the measure and the measurement of the potential of the sectors in the macro economy are made with the same explanations. an expression of the amount or value of the products produced, for example, a ratio in production. In fact, the capacity definition should not only be operated or downloaded to a production unit. It is also possible to accept as a relationship level (Brinkerhoff-Morgan, 2010: 4) the assumptions of acceptance that allow a set purpose to be realized and that the common acceptance towards which it takes place influences others.

We can include various definitions of capacity as follows.

- Theoretical capacity: The amount of production targeted at the maximum production rate by using all the means of the production vehicles in a given period.

- Technical Capacity: The amount of product that can be obtained by continuous work without any business organization.

- Maximum capacity: Technically and theoretically, they are used to each other. The only difference between maximum capacity and technical capacity is that there is no business organization at maximum capacity. It is difficult to obtain such capacitance due to definition and application (Gülerman, 1976, 109). Because, over time, their ability to produce means of production is reduced. Managers may not find the production factors at the moment of need. However, in the application of the defined capacity, only once is encountered. It does not repeat repeatedly.

- Economic Optimum Capacity: Defines the "Optimum capacity" of the production level where a unit product cost is minimized, and the production time at which profit and productivity are maximized is minimized. When inclusion of the profitability target is included, "EconomicOptimum Capacity" is determined. The production amount that the unit product cost is minimized is expressed as "Technical Optimum capacity".

- Normal Capacity: It is also used as the general expression of economic and optimum capacity definitions. Economic and technical optimum capacity and production policies including production costs, pricing, stocks, profit-loss development are determined. It is impossible to give a definite quantity because the normal capacity and the production level that can be achieved in the long term are expressed and carry subjective decisions.

- Actual capacity: The production level obtained from the production vehicles in a certain period. Actual capacity is based on current means of production, factors, and work organization. The situation of the current staff leads to the demand limits, the financial resources are scarce and inadequate, and the prices of these levels are reduced according to the changes in technology.

- Sector Capacity: The amount of production obtained by grouping the same goods and services produced by different production vehicles in a given period. Macroeconomic level communities are represented by the product capacities of all enterprises that produce a product range that can be counted to satisfy a certain need (Müftüoğlu, 1978,197). 
The description of the sector capacity and sometimes the economic and technical optimum capacity definition are also included. In addition, the actual capacity, expressed as the actual capacity, is related to the determination of the sector capacity.

- Unit capacity: It is the quantity of unit production means and factors according to production purpose. Unit capacity is included in other capacity definitions. The ability to produce the smallest parane bearing production capability describes unit capacity. This is also called "Basic Production Capacity".

Companies evaluate their capacity in terms of their aims and objectives, in line with their mission and vision, and try to produce a production amount using current production of human resources and production factors. Capacity sets out the amount of output as a measure of ability for businesses.

Here, the factors that determine the capacitance are needed. The factors that determine the capacity are labor and capital. Labor and capital refers to unit production.

a.) Labor Factor: It both forms the basis of the production process and is considered a function of the business organization. With this feature, it is possible to accept labor as both a worker and a business organizer. Labor is a sign of time and talent in the production process.

The production time indicator is the amount of time employees spend using production to achieve production. This does not include the time when the worker does not work as a rest, strike or accident.

The unit of work produced by the worker at the time of the unit is the ability indicator. It is not possible to determine precisely because the production ability is variable and subjective. Because social and psychological factors are influential in your ability to work. For this reason, it is used as estimated values.

It is more accurate to take the average of the unit production ability that the workers performed in the unit production time in the previous periods as definite value in determining the production ability. It is more accurate to use any unit production ability instead of unit average value. Labor in labor organiza- tion provides coordination of capital with production time of production ability. Relates and directs production factors with each other. In other words, productivity and profit is the main actor.

b.) Capital Factor: Capital as a function of production is also a factor in determining capital as fixed and variable capital. Increasing production, restructuring, conservation and use of production factors in a certain period in order to increase production of goods and services and increase consumption opportunities especially in future periods is a factor determining the capacity determinant (Sakızlı, 1981,21).

Fixed capital is represented by machinery-equipment, buildings and land, which are renewal and renovation investments, completion investments and new investments.

Although machinery and equipment investments involve the use of work machines and force machines, the capacity builds more on business machines. A factor of time capital used for the production of a unit of machinery equipment in enterprises. Technology and automation should be described to describe the production capability of the machine equipment.

Raw materials and auxiliary materials required for production and financial resources are capacity determinants as capital. Such determinants relate to production capability and production time in the period when the capital is produced. The size and structure of the 
industry or of the industry sometimes makes organizational structure based on time (İnan, 1985,194) essential.

Fixed capital participates as a means of production capability at the time of production. Its use is also continuous. However, material and financial resources are consumed during the production period and become final products. Although it is possible to specify the capacity of the work organization outside of labor and capital as the defining factor, it is better to think together with the labor factor. The work organization is carried out by the employees who are the organizers of the production purposes and tools.

The principles and principles set out in the work of selecting and operating the production factors, preparing and managing the work system are provided by the work organization.

\section{Capacity Measurement Criteria}

In the macroeconomic economy, the measurement of the capacity in the real economy, especially in the industrial sector, is to compare the change in production quantity and development over periods.

In these measurement enterprises, both production quantity is measured and production is compared with production in other enterprises.

Capacity measurements; Based on the difference between the amount of product produced and the amount of planned product, resource waste, use rate of production factors and added value loss are determined. Accordingly, new production capability is planned. the distribution of resources is rearranged and resource and time loss are prevented.

The most common criterion used in capacity measurements is the quantity of products. The difficulty of measuring with the amount of product is that it is more than one product produced at the same place. This difficulty is solved by aggregating the determinations of a single product type in a business by putting it into a sectoral classification in the general economy.

The products produced in one or more enterprises are brought together according to certain qualities and conditions and homogeneous grades are obtained. The product expressed as aggregated is either quantity or value. Capacity is either the quantity or value of the product. Quantity is expressed in terms of quantity, length, weight, area, volume, and the value is the sales amount TL. or US dollars, such as Euro.

The use of machine-equipment is also a capacity measurement criterion. Volume, volume, area are quantity determinants in capacity measurements, especially according to fixed capital investments. Depreciation (wear and tear shares) is a value determiner. The production time is explained as a time determiner.

The use of labor is also a criterion used in capacity measurements. The number of workers (employees) in the labor factor is the quantity measure. The cost of labor, ie the sum of wages, is a measure of value. Time measurement is the production time. As a measurement criterion in the industrial sector, the use of machine-equipment and product quantity and value generally has a more positive effect. Value added or output is the measure used throughout the economy as the production value.

Capacity input capacity calculated based on output capacity, labor and variable capital utilization is calculated as fixed capital capacity according to fixed capital usage (Demirgil, $1965,5)$. According to the production value we have taken as output capacity, the various products of the enterprises are used homogenized in the capacity measurements.

$\mathrm{F}_{\mathrm{t}}=$ Work time of the base productive unit. 


$$
\begin{aligned}
& X_{t}=X \text { unit production time of output. } \\
& Y_{t}=\text { Unit output time of } Y \text { output. } \\
& c(X)=\text { The output capacity of } X \\
& c(Y)=Y \text { Output capacity. }
\end{aligned}
$$

$F_{t}=X_{t}^{*} c(X)+Y_{t}^{*} c(Y)$ If two products are produced during operation, they will show the work time of the basic productive unit.

$c(X)=F_{t} / X_{t}$ veya $c(Y)=F_{t} / Y_{t}$ Production of only $X$ or $Y$ goods in the basic productive unit

From here,

$\mathrm{c}(\mathrm{X})=\left(\mathrm{F}_{\mathrm{t}} / \mathrm{X}_{\mathrm{t}}\right)-\left(\mathrm{Y}_{\mathrm{t}} / \mathrm{X}_{\mathrm{t}}\right), \quad \mathrm{c}(\mathrm{Y})=\left(\mathrm{F}_{\mathrm{t}} / \mathrm{Y}_{\mathrm{t}}\right)-\left(\mathrm{X}_{\mathrm{t}} / \mathrm{Y}_{\mathrm{t}}\right)$ A single product capacity will be determined according to the production time and capacities of different goods or services.

It will be possible to maximize profits and minimize costs by producing different commodityproducts and revealing the equations to be used in capacity determination according to the measurements of manufactured products.

The time and place of the capacity measurement is as important as the measurement criteria and the account. Business-based capacity measurement is carried out both in the main unitsunits where production takes place, and in the other units associated with production.

Outside the main Unit, the production capacity measured at each current unit is determined. The capacities found in product type are proportioned to each other and the determinations in the stage of final product output are determined as capacity.

\section{Analysis of The Relationship Between Capacity Utilization and Macroeconomics in}

\section{Enterprises}

Within the general economic structure, capital, natural resources and labor usage and the ratio in this usage are very important. In underdeveloped economies, capital stoke does not occur easily.

The realization of capital accumulation necessitates efficient use because it requires social sacrifice. Furthermore, the calculation and interpretation of the capacity utilization rates is an important indicator for the industry (Akpan-Essien, 2011,16).

If capital and labor are not used efficiently, significant losses occur in the economy. When the difference between the amount of production in which the capacity utilization is realized in the sector and the production that can be realized is determined, this difference comes out as a waste of resources as "lost production" and / or "lost added value".

Resource waste can lead to crises in the short and medium term. Because of this, it is desirable that the capacity utilization is complete. Crises caused by the use of incomplete capacity come to the optimum sector capacity in the long run where costs are minimized and profit is brought to the maximum level. The severity of crises diminishes in these periods and crises begin to fade. To arrive at full capacity, the optimum capacity must first be reached.

The optimum capacity at which the production costs are minimized and the profit maximized are related to both costs and production patterns. The production-cost relationship in the business is considered to be the same in the sectors as well. The fiscal function depends on the supply function of inputs used in production. The production function determines the relationship between inputs used for production and production. 
The assumption that the input prices used by the operator can be constant over the production time defines the relation between production and cost as "constant yield according to scale".

For production of a certain quantity $(\mathrm{P})$, it is necessary to take it from the input $(\mathrm{E})$ to the input $(\mathrm{E}),(\mathrm{F})$. Let us use DF1 instead of a unit (E) entry to perform the production of (P). Let's use E2, F2 to generate the same amount $(\mathrm{P})$ again. Here too, production of $(\mathrm{P})$ is achieved by using DF2 for production of $(\mathrm{P})$.

If E1> E2, then DF1 <DF2 becomes (Avralığlu, 1978:9) and this is called "Increasing Marginal Reputation Relative Principle".

It is sometimes possible to increase the production amount by increasing the other by keeping a constant E and F. Production occurs at a level where input marginal efficiencies and input prices can be matched, which may become a level where profit is the highest.

If the ratio between the increases in input prices is constant and all inputs are increased in the same place (eg a b), then if the production increases by $b$, then there is a non-fluctuating efficiency situation in the business scale.

It is possible for an operator with such a function to double the use of input and double the amount of production. The important thing here is that the costs will increase twice as much as the entries increase twice. that is, the production and cost functions of the business are linear. If the increase in the production of the operator is less than the increase in $b(b 1<b)$ then the operator will have a reduced yield at the production scale. In this case, the enterprise should increase the input quantities by more than twice in order to double the production quantity. Briefly, in this case the amount of production increases less than the amount of input. The cost function becomes an increasing function.

It is possible to mention the increased yield on the operating scale if the $b$ increase in the input quantity of the operator increases the production more $\left(b^{11}>b\right)$. Business can use less input to increase production twice as much. In this case, the cost function increases in less order. Although the unit costs are expressed as the savings resulting from the growth of the capacity (Süzer, 1981, 35), the savings from the scale are not the same in every business and sector.

The productivity of capital and labor determines the amount of production. When there is a change in the mode of production, the production capacity also changes. The change in capacity is a function of changing natural resources, capital and production techniques (Kazgan, 1974, 110). Increase in investment leads to an increase in income, which leads to idle capacity.

If the increase in income and the increase in investments are not correct, it will be inevitable for the idle capacity to emerge. So where should the investments be so that the increase in output and the increase in income are equal.

The power of production must be calculated correctly. In case there is no unemployment and inflation in the economy, production capacity will be important in determination of capacity increase and decrease rates.

$\mathrm{i}=$ annual investment rate, $\mathrm{s}=$ productivity achieved per unit with additional investment, $\mathrm{i}=$ annual capacity of investment $i$ is lower than the total capacity of new investments. Because $s$ shows capacity.

Because new investments will reduce the production of existing investments.

$\sigma s=$ actual capacity output

$\mathrm{P}=$ Production, $\mathrm{t}=$ Time, $\mathrm{I}=$ Investment 
$\mathrm{s}=(\mathrm{DP} / \mathrm{Dt}) / \mathrm{I} \mathrm{s}=\mathrm{DP} / \mathrm{Dt}$.

os will actually increase production, which will show us the rate at which the economy can grow. Although $s$ is taken as social efficiency of investments, it refers to the increase of production obtained per investment in a certain period.

The difference between s and s indicates that the investment is made incorrectly at some point. Technological development and labor are more invested than growth.

The investment made at one time must be greater than the savings at $\mathrm{t}-1$ to close the gap between increased capacity and income. If it is not big, the idle capacity will emerge. Labor and capital remain idle. The extent to which the idle capacity will affect new investments depends on the structural characteristics of the economy.

In developing countries, it is possible to increase the amount of output with efficient use of existing capacity because capital is not enough (Kalın, 1998, 171). The efficiency of capacity utilization also has a positive effect on capital stocks.

\section{Effects of Factors on Growth with Capacity Utilization}

Factors affecting capacity utilization can be classified in 6 groups. These are raw material inadequacy, problems with workers, financing problems, energy shortage, lack of tariffs. In particular, there is a shortage of domestic and imported raw materials in the manufacturing industry.

For example, if not enough polyvinyl chloride and polyethylene are produced in the chemical industry, it causes raw materials in rubber and plastics industry to be inadequate.

Inadequate production of one industry is the inadequacy of raw materials and materials for another sector. For example, leather processed in the leather processing industry is used as raw material in shoes and textile industry.

In an industry, foreign exchange bottlenecks are attracted, and imported raw material troubles are inevitably caused by exchange rate differences. Businesses also need to supply existing spare parts and use technological developments to continue their production.

Import inadequacy also appears to be an important factor in capacity utilization. For example, in 1978, 41.3 per cent of the factors affecting raw capacity in production capacity were in manufacturing industry. 22.5 percent of this was from imported goods and 18.8 percent was from domestic goods. In 1981, the impact of domestic goods on idle capacity was 20.8 percent and the impact of imported goods on 15 percent.

Affected by insufficient input of imported goods in investment goods producing sectors, it was 25 percent in 1978 and 18 percent in domestic inputs. The training, personality and technical skills of the employees of the industrial companies differ in quality.

The private sector is entering after retirement from the public sector, both educated and uneducated. The private sector of experienced and qualified workers in the public sector and the public sector operations are greatly affected. But this effect is not the same in the private sector after gradual transitions. the private sector has to educate its own employees to train. As such, the time lost for training and study affects capacity utilization. In addition, applications such as strikes and lockouts are also impressive factors in capacity utilization.

For example, the impact of the problems related to the employees in the investment goods manufacturing industries was 12 percent. In 1981, this rate dropped to 4 percent. The continuation of production requires the discovery of financial issues. 
This is necessary for both the public and private sectors. The difficulty of finding a loan for an enterprise is due to the high cost of lending and the bureaucratic issues in its possession.

In addition to the cost of loans, producers can not be turned into money quickly, thus reducing the production of enterprises. This increases product costs and affects capacity utilization.

In 1978, the capital of the companies producing investment goods was affected by the financing due to financing, and it was around 16 percent in the sectors producing consumer goods. In 1981, the investment incentives of the sectors that produce investment goods is 11 percent.

Although the restriction that energy can come into play has affected the idle capacity by about five percent in the 1980s, the measurements are not certain because there is no interruption today. Businesses should be able to sell their products in domestic and foreign markets.

Capacity also changes as the demand for products in the market changes.

Businesses often make the wrong feasibility of keeping demand high to find a loan, which can change the capacity utilization of businesses if the mistakes are not enough to demand the product on the market. For example, in 1978, 28 percent idle capacity was created with inadequate demand in sectors producing investment goods. This ratio has increased to 29.3 percent in 1981.

In addition to the inadequacies of transportation services, the non-optimal decisions of the managers (Cloud, 2004: 1) are among the factors affecting the formation of the capacities. The factors that influence capacity utilization should be tested to determine what capacity and what size of capacity they are using.

\section{Conclusions}

Since capacity utilization is related to efficient use of resources, it is expected that interest policy will be effective in the period when capital supply and demand is sensitive. It is especially useful to use a cheap business loan. the banking sector should provide support with long term loans.

The second shift should be encouraged in the industry. Particularly exporting sectors should be supported. New incentives should be used. It is inevitable that the incentives given by the economies in which the unemployment is continuous and structured go to the employers. But it will be seen later that the increase in production provided by shifts will also increase employment.

It should be directed towards working with full or full capacity with tax policies. for example, the production tax from 2 nd and 3rd shifts should be taken less frequently. In this case, the tax on production will decrease somewhat, but the total tax revenue will go parallel to the increased production.

Inadequate demand and raw materials can be reduced by the inadequate capacity of the administrators. In this sense, public and private enterprises should closely follow the decisions of the managers according to their own production.

The aim is to increase the capacity utilization of the total industry while creating monetarycredit policies and selecting technology. This will be important for production and income growth. It is essential to create a technology policy. High production (high capacity utilization) should be kept in the foreground rather than avoiding capital intensive technologies and capital imports. 
Capital-intensive technology investments in foreign currency must be exercised at maximum production level in absolute terms. By doing this, total factor productivity will be increased and new arguments will be provided for inflation targeting.

Assessment of the calculation of idle capacitance is very important for macro planning. If there is idle capacity, it will be necessary to enlarge the Capital / Reasonable Rates. Because the targeted growth will not be realized with the desired capital investment realized.

The capacity gap will not allow this. As long as the current capacity is idle, the capital / revenue ratio will need to be increased to achieve the targeted output. The full utilization of the existing capacity will also reduce the capital / product rates to be used in plans and programs.

In other words, the target output level can be achieved by increasing capacity utilization against less capital investment.

\section{References}

Akpan, S.B. - Udo,U.J.- Essien, U.D. (2011). Influence of firm related factors and industrial policy regime on technology based capacity utilization in sugar industry in Nigeria. Agris on-line Papers in Economics and Informatics, Vol 3, No 3, Page 16.

Avralığlu, Z. ( 1978). Üretim Fonksiyonları, AİTíA Yayını, Ankara, Sayfa 9.

BrInkerhoff, D.W. Morgan, P.J.( 2010). Capacity and Capacity Development: Coping with Complexity ${ }_{\iota}$ Public Administration and Development, Sayfa 8.

Bulut, Z.A.(2004). İşletmeler Açısından Kapasite Planlamasına Etki eden Faktörler. Mevzuat Dergisi, Vol 7, Say1 80, Sayfa 1.

Demirgil, Y.( 1965). Kapasite Kavramı Hakkında Not, Devlet Planlama Teşkilatı Yayın, No 211İPD87, Sayfa 7.

Gülerman, A. (1976). Mühendislik Ekonomisi, Ege Üniversitesi Mühendislik Fakültesi Yayını, İzmir, Sayfa 109.

İnan, Ö.( 1985). İşletmelerde Yönetim, Fonksiyonlar ve Organizasyon, Baytaş Yayını, Ankara, Sayfa 194.

Kalın, R.K. (1998). Factors Affecting capacity Utilization in Manufacturing Sector of Pakistan: A Survey Analysis. Pakistan Economic and Social Review, Vol 36, No 2, Page 171-182.

Kazgan,G.(1974). İktisadi Düşünce ve Politik İktisadın Evrimi. Bilgi Yayınevi, Ankara, Sayfa 110.

Müftüoğlu, T.( 1978). Sanayi İşletmelerinde Üretim Kapasitesi, Ankara Üniversitesi Yayını, No 422, Ankara, Sayfa 197.

Otoo,S.-AGAPITOVA,N.,-Behrens, J. (2009). The Capacity Development Results Framework, World Bank Publishing, Page 2. 
Journal of Business Management and Economic Research, vol.2, issue.11, pp.38-47

Sakızlı, E.( 1981). Temel Ekonomik Kavramlar, Proje Geliştirme ve Seminer Notları, Devlet Yatırım Bankası, Ankara, Sayfa: 21

Süzer, M. (1981). Kapasite Seçimi. 14 nci Proje Değerlendirme Semineri, Ankara, Sayfa 32.

Şimşek, M.Ş.( 1998). İşletme Bilimine Giriş, Nobel Yayınları, Sayfa 97. 